\title{
Implementation of Arts Education in Society Through The Thematic Community Service Program
}

\author{
${ }^{\otimes} J_{u j u}$ Masunah ${ }^{1}$, Lely Kurniawati ${ }^{2}$ \\ ${ }^{1}$ Department of Dance Education, Faculty of Arts and Design Education, \\ Universitas Pendidikan Indonesia, Indonesia \\ ${ }^{2}$ Department of Early Childhood Teacher Education, Faculty of Education Science, \\ Universitas Pendidikan Indonesia, Indonesia
}

Received: March 15, 2018. Revised: July 2, 2018. Accepted: December 12, 2018

\begin{abstract}
Since the transmission of arts education in the family is limited in Indonesia, the exploration of teaching strategy for community becomes imperative as a form of informal education. This article aims to report research results on the implementation of arts education in society through thematic community service program, namely Pos Pemberdayaan Keluarga (POSDAYA) or "family empowerment post." This qualitative study used a project-based research method, which began by diagnosing the problems, creating a plan for activities, implementing the plan, and evaluating the results. Participants of this research were women and children from Bandung Barat Regency of West Java and students of Universitas Pendidikan Indonesia. Data were collected from interviews, participant observation, and study documentation. The data were triangulated and interpreted. The research found a collaborative teaching strategy between students, advisors, and women who worked for POSDAYA to implement arts education for children through creating dances and musical dramas. The story in the drama contains moral values such as caring for others, appreciating one's parents, tolerance, and environmental awareness. Implementation of arts education through the community service program conducted by students and or faculty members is beneficial to develop children's creativity and character.
\end{abstract}

Keywords: Arts Education; Dances For Children; Community Service Program, Family Empowerment Post

How to Cite: Masunah, J., \& Kurniawati, L. (2018). Implementation of Arts Education in Society Through The Thematic Community Service Program. Harmonia: Journal of Arts Research And Education, 18(2), 131-142.

\section{INTRODUCTION}

A community service program conducted by students is one of the teaching and learning activities in higher education in Indonesia. This program in Universitas Pendidikan Indonesia (UPI) is a compulsory course subject that should be taken by all undergraduate students (LPPM UPI, 2016), but other universities consider it op- tional. Since 2009, the Research and Community Service Institution (LPPM) in UPI has implemented the community service program for students using themes or thematic programs. One of the themes is "Pos Pemberdayaan Keluarga (POSDAYA)," or "family empowerment post". This theme was created by the Damandiri Foundation in Indonesia to help low-income families increase their welfare. The thematic com-

\footnotetext{
${ }^{\square}$ Corresponding author: Setiabudi Street, Bandung 40154, Indonesia

E-mail: jmasunah@upi.edu
} 
munity service program, POSDAYA, aims to establish a forum for communication within social organizations in the community and to strengthen the roles of families to mutually share knowledge and experiences to increase welfare in the community.

In this context, advisors for the thematic community service programs along with the students are encouraged by the institution to collaborate with members of a community to increase their knowledge and skills based on each advisor's expertise. Since 2010, we have actively participated in programs involving students to implement activities in the field of arts education. In 2011, one of us (Ms. Masunah) worked collaboratively with UPI students, women, children and artists in Ciater Village of Subang, West Java, to create a form of performing arts to attract tourism (Masunah, 2012). However, after the program ended, many forums could not continue the activities that the students had created together with the members of POSDAYA. Therefore, when Ms. Masunah, was appointed an advisor again for the same program in 2016 in West Bandung Regency of West Java, she created activities to incorporate arts education for women and children in the community. She believed that women as mothers play a role in educating their children informally due to the unlimited space and time at home.

In Indonesia, arts education in the community has been developed informally over the course of time within various spaces. This case can be traced back to the roles of performing arts in society. Soedarsono (2002) wrote that performing arts serve as a part of rituals, personal entertainment, and aesthetic presentations. Through these roles, the knowledge and skills of the arts are transferred and accessed by the children in the community, so the performing arts, like mask dances from Cirebon continue to exist until today. For example, Masunah (2000) wrote how Sawitri, a traditional dancer of mask dance from Losari in Cirebon, learned mask dances from her father and older sister through watching their performances, hearing the gamelan, and practicing dance during the tour or performance in the community. Then, Sawitri taught mask dances to her family members in Astana Langgar village, Losari, Cirebon. Sal Murgianto, in his book of Cahaya Merah Memudar (1993), described how the children in Bali learned dances by watching adults during dance practices.

Caturwati (2008) published some articles in the edited collection Tari Anak-anak dan Permasalahannya [Children dances and their problems], which discuss strategies and methods to create dances for children and show some examples of children's dances, such as "kariaan [ceremonial] dance," "traditional game dance," and "dance choreography for children." This book provides knowledge for teachers and people who want to explore children's dances. However, the implementation of this knowledge in society is still missing in the discussion. So, we once again served as the advisor for the community service program in 2016, we did research and worked collaboratively with the students and the people in the family empowerment forums to train people in arts education, particularly for women and children.

The purpose of this research is to find a strategy to implement arts education in a society that provides knowledge and opportunities for women to create children's dances. According to Mariam Giguere (2011), there are three forms of children's dances, namely dances for children, with children, and by children. The research explores dances for children as part of the implementation of arts education in the thematic community service program, namely POSDAYA or the family empowerment post.

\section{METHOD}

The research took place in Parongpong Sub-District, Bandung Barat Regency, West Java, Indonesia. Parongpong Sub-District is located close by North Bandung City. The activities took place in seven villages in Parongpong Sub-District, 
namely Cigugur Girang, Cihanjuang Rahayu, Cihanjuang, Cihideung, Ciwaruga, Karyawangi, and Sariwangi. Each village has a forum of family empowerment posts where the students of UPI conducted their community service program. The research involved 21 women who actively worked for the forums of family empowerment post, called women pioneers, students who worked for the community service program, and researchers as the participants.

This qualitative research used a project-based research method (Stoecker, 2005). According to Stoeker (2005), one of the characteristics of this method is the contribution it makes for a social change of individuals, organization, community, and even society. This research began by diagnosing the problem, creating a plan for teaching adults, implementing the plan, and evaluating the results.

Before creating a plan to implement arts education for women in the community, we prepared the materials by selecting fourteen children's songs and compiling them in a $C D$, searching for stories appropriate for children, and designing teaching activities for adults. We coordinated the students to work with the women in the field and to organize the workshop of arts education as well as to create dances for children. Each group of students selected two representatives to participate in the workshop, while each family empowerment post invited three women to attend the workshop. Other students acted as committee members to organize the workshop. The advisors and researchers were represented as speakers, trainers, and evaluators of the project.

Then, we diagnosed the problems by asking whether the women sing children's songs, make creative movements, and tell stories for children in their daily life. From 21 respondents, $90 \%$ of them did not do any of the activities; only $10 \%$ of the respondents sing children's songs and tell stories for their children. It can be said that $10 \%$ of the mothers contributed to their children's early childhood education.
Our expertise as the advisors for the community service program at UPI is in dance and music, so we created a plan to teach the mothers to sing, to dance, and to tell stories, then we led them to create dances for children. We used Mariam Giguere's (2011) concept of dances for children. Then, to implement the concept, we designed the syntax for teaching dance which begins by introducing a concept, exploring movements, creating a dance, and presenting the dance (Masunah et al., 2012). Because this research involved adults who did not have enough experience with children's songs and the elements of dance, we modified the steps of synectic approach by adding training activities after introducing the concept. The next step is exploring the movements using analogy and various stimulating actions, such as ideas, visual, audio, kinesthetic, and tactile stimuli. Music is related to the audio stimulus. Lely Kurniawati (2015) stated that learning music by itself will be boring, making it necessary to combine music with movements to make teaching and learning interesting. Also, music can stimulate students to explore the movements. The materials for dances to be explored in the creative process are the elements of dance, such as the body, time, space, and energy. The final product of the project is a dance for children involving the work of adults.

Therefore, we treated adults as students who conducted a community service program and the women as pioneers of the family empowerment post. The project was completed in two stages. In the first stage, we held workshops on arts education for adults, namely for the women and the students of UPI. In the second stage, we supervised the adults in creating dances for children. The project was held from June to August 2016. We evaluated the project from the process of the workshop through to the performance of the dances created for children.

\section{RESULTS AND DISCUSSION}

A Workshop of Arts Education for 
Adults

The purpose of the workshop is to increase knowledge, experience, and skills of adults on understanding the concept of educating children, using materials as a source for creating dances for children, and doing creative processes to compose and present the dance. The workshop was held on July 20, 2016, in the auditorium of Parongpong Sub-District, West Bandung Regency. There were 21 women and 14 students who participated in the workshop. Materials included children's songs, creative movements, and storytelling. As we modified the synectic approach from Masunah (2012) discussed above, the activities in the workshop began with introducing the concepts of educating children, followed by training the adults with songs, exploring the movements, telling a story to give ideas of dances and moral values, and creating and presenting the children dances performed by adults.

We introduced two concepts to the adults (women and students) about educating children: creativity in arts education and moral values. Creativity is the heart of art education because it relates to thinking and behaving. This can be seen from the creative dance approach developed by Gilbert (2002). Gilbert (2002) uses a conceptual standpoint that leads people to make self-expression and develop their skills through movements. Maralsih and Herlinah (2014) stated that "creativity is an ability to think about something in a new way" (p. 148). Children will have developed ideas through thinking about themes of dance. They will also explore the elements of dance by acting like animals, flowers, or abstract things, for example. During the practice, children will work with peers, and parents or teachers can observe how they behave when they work together. According to Maralsih and Herlinah (2014), the creative process of dance creation will affect students' creativity.

The moral values are discussed in connection with character education. In the 2013 curriculum, character education is required as part of the learning outcomes, like spiritual and social competences (Ministry of Education and Culture, 2013). According to Gilbert (2002), as the impacts of learning creative dances, children will gain cognitive, affective, physical, and social skills. Through concrete examples about the cases of children's and adults' behaviors, the participants will understand how to educate their children through arts.

The next step in the workshop is training adults to develop their skills in children's songs and creative movements. Lely Kurniawati, one of the researchers and lecturers in the early childhood teacher education program at UPI, trained the participants to sing several children's songs that she created by herself, such as "Hey Hello Siapa Namamu [Hi Hello What Is Your Name]," "Semua Alat Musik [Every Musical Instrument]" "MeJiKuHiBiNiU", "Maju Mundur [Moving Forward and Backward]", and "Jagalah Lingkungan" [Save the Environment]. She also taught others songs, such as "Tebak Cita-cita [Guess My Dreams]" "Soleram", "Anak Kambing Saya [My Lamb]", "Tokecang", "Orayorayan" [Imitating the Snake], "Lalamunan" [Dream], "Niron Tentara [Imitating the Soldier]", and "Gumbira [Happiness]". The participants practiced the 10 songs, and then Kurniawati taught the women rhythmic movements based on the songs. It seems the women already knew some Sundanese songs. Therefore, Kurniawati emphasized teaching the songs in Indonesian language until the participants remembered the lyrics.

After the participants learned singing skills, the dance instructor trained them with elements of dance such as the body, space, time, and energy. Before doing the movements, the participants identified parts of their body which can be moved in locomotor and non-locomotor movements. They warmed up by exploring the hands, shoulders, head, and legs. Then, the researchers instructed participants to use rhythmic songs for exploring the movements through energy, time, and space. The women were actively working in the group while they were singing children's 
songs and stylizing the movements.

To give some ideas about embedding moral values in the practice of dancing and singing, we also told stories. We read stories about "Kupu-kupu Merah [the Red Butterfly]" created by Rendila R. Utami (2016), and the well-known story in Indonesia about "Si Kancil" [the Clever Mousedeer] (Elang Duta, 2015). The red butterfly tells the story about various colors of the butterfly; the red one is very friendly to others. The story "Si Kancil" represents dishonesty, even though si Kancil is a clever mousedeer. Kancil frequently stole cucumbers in the farm, and so one day he was caught by the farmer, and he was finished. The women created personal and direct analogies about Kancil and the farmer. In order to provide the structure of the dance, one of the women acted as a director of the musical drama. She organized the participants to play as Kancil, the farmer, butterflies, trees, and flowers. They created dances accompanied by the children's songs.

During the presentation about the musical dramas, the women were not aware of the stage. Therefore, we taught the women to be aware of the audience in their performance. The women practiced without problems for the context of the performance. Finally, they presented dances in the musical drama of "Si Kancil". Through the activities, the women understood the concept of creativity and the moral values in the work of dances.

Referring to Smith's construction method of dance composition or choreography, as cited in the book Art and Art Education (Masunah \& Narawati, 2012), storytelling is the ideational stimulus and the songs are the audio stimulus. Through these stimuli, women who rarely danced perform their ability to dance and in dance-making. They felt the workshop was beneficial for them to teach their children when they get home. The students who participated in the workshop also promised to work with the women in their POSDAYA to implement their knowledge and experiences to educate the children in the villages.

\section{Creating Dances for Children in the Mu- sical Drama}

As a follow up to the workshop on arts education, the students and the women created dances for children in their respective villages. The purpose of this second step is to learn how adults create and work with children collaboratively.

Giguere (2011) described dances for children created by adults as "cultural creations, or creative products, that adults have made for children's consumption." In this context, the children are the product of adults' education and experiences, either teachers or choreographers in the studio. The aesthetic values of the choreographers or the teachers will appear in the dance that is presented in the practice and performance. According to Giguere, "These formats allow for a showcase of skills learned by the students to be displayed" (p. 85). The strength of this approach lies in the connection between the students and the teachers, the choreographers, the studios, and the local dance community. The weakness of this method is that the children cannot be involved in the process of creating dances. The other approach is "dances created with children and adults" (Giguere, 2011, p. 86). This approach allows children to give some input to the final product of the children's dance. The role of the teachers or choreographers is to give instructions and to form the dance. The approach of "dances created by children without adults" (Giguiere, 2011, p. 87) is a creative process and product of dance created by children themselves. This approach is usually intended for teenagers who have freedom of expression. They can solve their own problems, have creative thinking, and are in search of personal identity. They also can work collaboratively with peers.

For the purpose of this study, we used the concept of dances for children offered by Giguere (2011) to examine the types of children's dances in the work of musical dramas. Therefore, there are simi- 
lar steps in the creative process of arts education in the community. In the first step, the adults make stories to be written down into the script of musical drama. The script contains a story, songs, music, and moral values. Then, the students along with the women organize practices with the children, such as looking for appropriate places to practice and perform, making a schedule, and designing costumes for performances. Every POSDAYA used various places like the space for creating and presenting the musical, such as the auditorium of the village's office, the family room, the mosque, and the house yard. From July 22 to 29,2016 , the students of UPI worked collaboratively with the women and children in the villages to make dances for children. In the end, the advisors of the students visited the seven villages from July 30-31, 2016, to evaluate the children's dances as the final products.

The Musical "Saudagar Jeung Bendunganana" by POSDAYA Karya Mandiri in Karyawangi Village

The title of the musical drama in Karyawangi Village was "Saudagar Jeung Bendunganana," (the Rich Merchant and his Dam) written by the students who conducted the community service program. The story is rooted in the village, regarding a merchant who was wealthy (saudagar), but he only thought of himself. In the story, the rich merchant built a dam for the irrigation of his rice field without considering the people in the village. The impact was that people had trouble finding water for their rice field irrigation. The son of the rich merchant was unfriendly with his peers and naughty. One day, the son of the rich merchant was sick. Fortunately, the people from the village who had the ability to cure illnesses helped the rich merchant cure his son's illness. These people's attitude touched the rich merchant's heart and made him aware of the people around him. He then opened the dam for the welfare of the community. This story was discussed by the women pioneers of the family empowerment post. Then, they also discussed the actors, the dancers, the singers, as well as the audience.

The women served as narrators, actors, and singers, while the students worked as music composers, choreographers, and committee organizers. The children explored traditional games such as "Orayorayan [Imitation of the Snake]" and "Panen [Harvest]". They practiced and performed in the aula of Karyawangi's office. Ten children stayed in line, while their bodies moved left and right following the rhythmic song of "oray-orayan". Two children had a role to catch up to the last children who stayed in line. The dance movements consisted of steps forward along with shaking the head, and the hands' movement resembled people walking. The girls wore kebaya and long skirt. The music used minus one with gamelan, while the songs were sung by the women pioneers of POSDAYA and one village girl, while the students of UPI managed the music and backstage crews. The location of performance was in the auditorium of the Village's office.

In the musical drama, there were two boys representing the guards of the rich merchant's son. They wore sunglasses and acted like adult bodyguards. They disturbed the girls who played in the yard. As children's musical drama, the two boys did not fit the figure of children, because they acted like adult bodyguards. If they had acted naturally as naughty boys, the musical drama could be more appropriate for children. Fortunately, the strategy of collaborative work between the students of UPI, the women, and children was very successful, because the women participated actively as performers and audiences.

The Musical "Usep yang Berubah" by POSDAYA Terasa Beriman in Cihanjuang Village

The story of the musical drama staged in Cihanjuang Village was titled "Usep yang Berubah [the New Usep]." This story describes the change of Usep from being a naughty boy to a good boy. Usep lived with his grandparents because Usep's parents passed away when Usep was born. 
Usep's grandparents were busy working in the rice fields, so Usep did not have enough attention from them. Usep always disturbed his friends, particularly the girls, even his teacher and other adults. Usep's grandparents could not handle Usep's bad behavior; therefore, the grandparents sent Usep to a religious boarding school. However, Usep dropped out of the school and stole the money of a jamu (herbal drinks) seller. On his way to get back to his grandparents' home, Usep was crashed by a motorbike, until he fell unconscious. When Usep gained his consciousness, he came to realize how bad his attitude was. Finally, Usep changed into a good boy and became obedient to teacher and grandparents.

In the performance, there is a dialogue between Usep and the grandparents. The character of the teacher was played by a child, while the other children danced and made games. The songs chosen were relevant to the story. For example, when Usep woke up, the song was "bangun tidur" [Getting Up]. When Usep went to the school, the song was "oh ibu dan ayah [Oh Mother and Father]". When Usep said that he wanted to be a soldier, the song was "Niron tentara" [Imitating the Soldier], and when Usep met a jamu seller, the song was "sue ora jamu". The dance movements were matched with the music and songs. All the characters were represented by children. The children looked happy and enthusiastic to dance and sing together. The moral value embedded in the musical drama is an appreciation of one's parents.

The women pioneers of POSDAYA played their role in preparing the hall and the music. The songs were selected and recorded by a woman who actively taught at an early childhood education school. The teacher also had access to a hall that can be used for teaching and practicing the dance.

\section{The Musical "Si Landik Yang Kesepian"} by Posdaya Asri in Sariwangi Village POSDAYA ASRI in Sariwangi Village presented "Si Landik yang Kesepian (The Lonely Landik)" by 21 children and 4 women. "Si Landik yang Kesepian" is a fable, which tells about animals, namely a porcupine or Landak who is called "Landik", a turtle, a dog, a rabbit, a tiger, and other animals. Landik lived alone, far away from the other animals, because his body was fully covered with quills. He was unconfident, unhappy, and always afraid that his quills would hurt others. One time, the turtle persuaded Landik to join his birthday celebration party. Finally, Landik joined the other animals and they had a great time at the party. Suddenly, a tiger came and launched his attack. Landik was able to protect his friends from the tiger by attacking the tiger with his quills. The story contains a lesson for children to be confident, appreciative, and helpful to other people.

For young children, the story of animals is interesting. They imitated the animals by wearing head accessories made of paper representing the characteristics of certain animals, combined with a long skirt and t-shirt. The girls wore kebaya and cloth designed for children. The boys wore pencak silat costumes.

To create a variety of movements, the musical used eleven songs to accompany the dances. The students took five songs from the CD, such as "Hey Hello" as an instruction song, then the children moved backward and forward accompanied by "Maju Mundur" song. The children also moved in a circle into "Mejikuhibiniu"'s song. They delivered a message to save the environment with the songs "Jagalah lingkungan" and "Lalamunan". The students who conducted community service program added some songs like "Sipampa", "Dengarkan Curhatku" (Listen to My Heart), "Sang Kodok" (The Frog), "Selamat Ulang Tahun" (Happy Birthday), "Hip-Hip Hura" (Hip Hip Hooray), and "Kelinciku" (My Rabbit). The women pioneers of POSDAYA took part as narrators in the musical drama and organized the activities as a whole.

The children practiced and performed their dances in the house yard of a villager. The yard was decorated as a hall for the performance. The collaborative teach- 
ing of POSDAYA ASRI was a successful one because the women, the students, the community, and children worked cooperatively, either in the process or in the presentation of the product. In fact, their product was selected as the best musical drama compared to the other six musical dramas. Therefore, "Si Landik" musical drama was performed at the end of the community service program in Parongpong Sub-District on August 2, 2016.

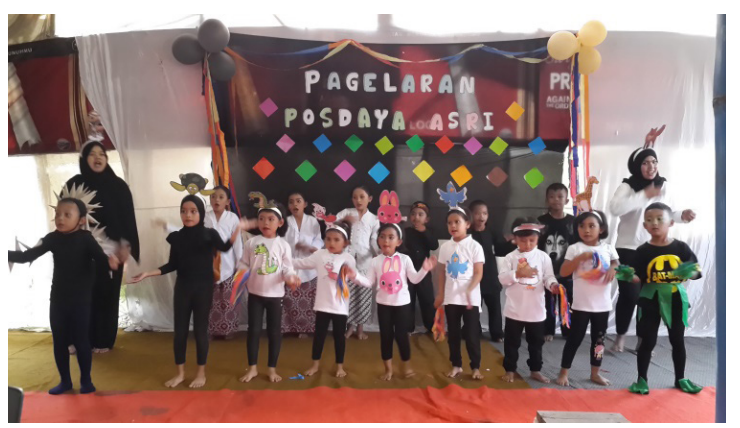

Figure 1. Children's dance by Posdaya Asri (Doc. of Masunah, 2016)

The Musical "Putri Elsa dan 1000 Merpati" by Posdaya Pandawa in Ciwaruga Village

The story of "Putri Elsa dan 1000 Merpati (Princess Elsa and the 1000 Birds) " describes Princess Elsa as a daughter of the King who had many birds. Some of the birds were given by people in the kingdom. There was only one child who did not give a bird to the princess; rather, he gave her a ribbon. Princess Elsa really needed one more bird to reach a number of 1,000 birds because she already had 999 birds. Suddenly, a bird with a blue ribbon flew by and stood next to the 999 birds. Princess Elsa was so happy because now she had 1,000 birds. Unfortunately, a child came to pick up the bird. The child said to Princess Elsa that to buy that bird the child had to save money for a year. Finally, Princess Elsa returned the bird to the child. In the following days, the child came back to the princes and gave the bird back to the princess. Princess Elsa was surprised by the child's action. The child explained that she took the bird away from the princess because it was sick. The child would like to take care of the bird until it became healthy before returning it to the princess. Princess Elsa was surprised by the honest and loyal child, and then the princess asked the child to take care of all birds in the Kingdom. The child was very happy to receive the job from the princess. At the same time, the princess learned how to appreciate people because there were unfortunate people who were not as lucky as she was.

When Princess Elsa held a birthday party, the children presented dance movements integrated with children's songs. The songs were "maju-mundur" and in the final dialogue the children sang "pelangi" song. The movements followed the rhythm of the songs: moving forward and backward, jumping, and moving in a circle. The story and the costumes fitted children's characteristics. The costume is like the daily clothes and the accessories were made from paper. The story contains moral values to appreciate others. The children were very happy in dancing, singing, and acting. They practiced and performed in a small mosque or musala. Unfortunately, the women of the family empowerment post did not get involved in creating dances for children; instead, it was the students of UPI and the mothers of the children who prepared everything. The mothers of the children who attended the performance were happy that their children joined the activity to sing and dance.

\section{The Musical "Angsa yang Buruk Rupa" by Posdaya Muda Mandiri in Cigugur Girang Village \\ "Angsa yang Buruk Rupa (The Ugly \\ Swan)" describes one of four cygnets who} had a "different" look. The ugly cygnet was always alienated by her siblings and friends; therefore, she always stayed alone. One time, there was a rabbit that got carried away by a flood caused by heavy rain. No one could help the rabbit. Fortunately, the ugly cygnet took the risk to save the rabbit's life from the heavy flood. The story implies the social value of helping each other.

Several songs were selected in con- 
nection with the story, beginning with the introductory song "Jagalah Lingkungan [Save the Environment]", then "Kupu-kupu [Butterfly]", "lalamunan [Dream]," "Hey Hello", and at the end, "Pelangi [Rainbow]". The location chosen to practice the dance and perform the musical drama was the hall of the office village in Cigugur Girang. There were about 50 children who participated in the event. The students from UPI facilitated the children as trainers, musicians, narrators, and costume designers, as well as MC. The women of the family empowerment post supported the event, even though they did not join the performance.

\section{The Musical "Si Hitam yang tak kenal Le- lah" by Posadaya Pamaneuh Rasa, in Ci- hideung Village}

The story from POSDAYA Pamaneuh Rasa was "Si Hitam yang tak kenal lelah (The Black Ant Who Never Gives Up)" or "The Black Ant Who Never Gives Up." It was told that a black ant, a king of an ant kingdom, along with all ants was walking to a certain place. While they were walking, they sang the songs such as "Kukururuk, (Cock a doodle doo)," "Hey Hello siapa nama Mu [Hi Hello What is Your Name]," "Bunyi hujan [Sound of the Rain]," "Pelangi [Rainbow]," "Maju-mundur [Moving Backward-Backward]," and "Jagalah Kesehatan [Take Care of Your Health]". The story represents an ethos of work. They practiced their dance in a small mosque. In the beginning, the children looked so shy. After they sang the songs, the eleven girls looked very happy. From this activity, they developed confidence and courage to present the movements in front of their mothers and the researchers. The mothers said that the children's dance could be performed in the night of Independence Day celebration, 17 August.

The Musical "Selo Harimau Cantik yang Sombong"'" by Posdaya Juang Rahayu in Cihanjuang Rahayu Village

The musical drama in Cihanjuang Rahayu village was very attractive becau- se many early young children and primary school age children participated in the event. The story of "Selo Harimau Cantik yang Sombong (Selo the Beautiful but Arrogant Tigress)" describes a beautiful tigress that was arrogant. She did not appreciate other animals, because she felt the best. Eventually, she came to appreciate the other animals, after one particular animal helped solve Selo's problem.

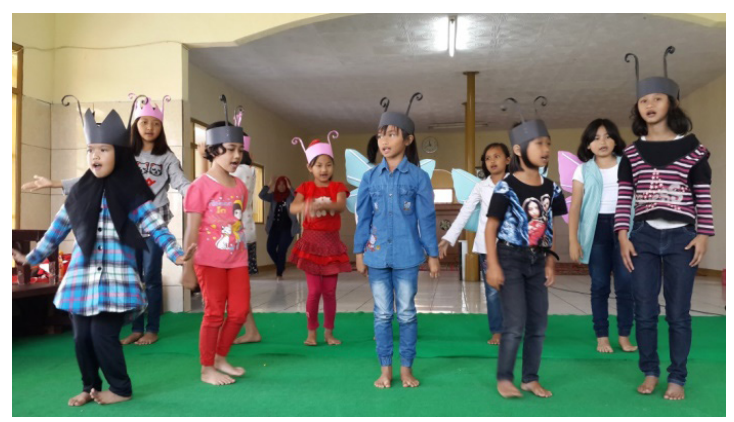

Figure 2. Children's dance in Cihideung Village (Doc. of Masunah, 2016)

The children performed children' songs and children's dance, and there was a talented child who performed Jaipongan dance. The students of UPI collaborated with the women of the family empowerment post to handle the event. The head of POSDAYA supported the children by providing a place in the yard of POSDAYA's office for children to practice. Most of the women in this village were busy with their daily business because during the day they sold flowers. Therefore, the children spent the day by doing meaningful activities with the students of UPI to practice and perform their dances.

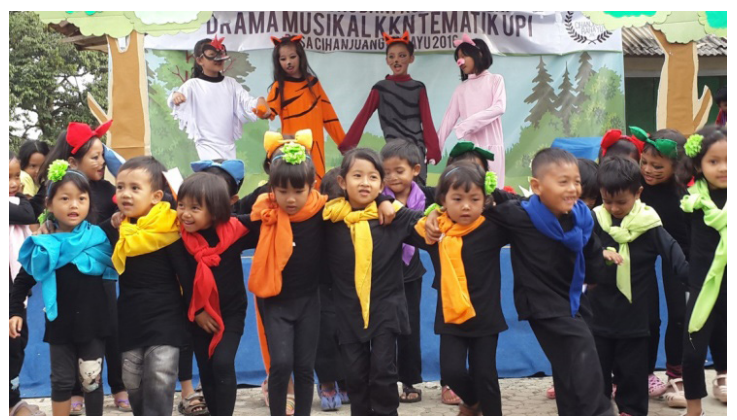

Figure 3. The Musical drama in Cihanjuang Rahayu Village (Doc. of Masunah, 2016) 
The Analysis of Implementing Arts Education in Society

Collaboration is a strategy of implementing arts education in society. In this research, the collaborative work was made among the students, the advisors, and the women pioneers of POSDAYA. The seven POSDAYAs in Parongpong Sub-District successfully created dances for children.

Examining the children's dances created in the musical dramas described above, we came to a conclusion that the dances are classified as dances created by adults (Giguere, 2011). They have two categories of presentations. First, dances for children created by adults and presented by children. There are four villages whose dances belong to the first category, such as Cihanjuang Rahayu, Cigugur Girang, Cihideung, and Ciwaruga. The second category is dances for children created by adults presented by children with adults. They are three POSDAYAs included under this category, such as Sariwangi, Karyawangi, and Cihanjuang.

The moral values embedded in the story performed are mostly concerned with social values. Social values are contained in stories with characters interacting with each other. This interaction between characters can be seen in the stories staged by the villages. For example, POSDAYA ASRI in Sariwangi village presented the world of animals, in which the animals interact with each other and they work together to help make "Landik" become confident and sociable. Another example is POSDAYA Karya Mandiri in Karyawangi village. The musical drama titled "Saudagar jeung Bendunganana" they staged contains a message to share with others in need. POSDAYA Pandawa in Ciwaruga foregrounded the values of understanding as is demonstrated by Putri Elsa. POSDAYA Terasa Beriman in Cihanjuang village presented "Usep yang Berubah", representing the value of appreciation for one's parents. POSDAYA Pamaneuh Rasa in Cihideung Village worked with "Si Hitam yang Tak Kenal Lelah" which conveys the message of work ethic.
POSDAYA Mandiri in Cigugur Girang Village teaches tolerance and environmental awareness through its "Angsa yang buruk rupa". POSDAYA Juang Rahayu in Cihanjuang Rahayu Village teaches cooperation through the performance of "Selo, Harimau Cantik yang Sombong". All of the musical dramas contain character education. When we refer to the 2013 curriculum, social values are required as social competence of learners (Muhamad Nuh, 2013). Social values in the character education are related to living values. Kokom Komariah (2016, p. 37) explained that living values are the foundation of human relations with themselves and with others. It is important that social values are embedded in the practice of teaching arts education because Indonesia is a pluralistic society. In urban areas, children live with people who are different in terms of culture, language, gender, social class, and religion. It is important that children have the moral value of tolerance to live in society.

The syntax that is applied to create the musical drama in all POSDAYAs matched Mary Joyce's concept of creative dance. Joyce (1994) describes teaching dance for children, beginning with introducing the concepts, exploration, and formation. In each respective village, the students were first introduced to the concepts through stories, and then the students explored the movements directly trained to them while singing the songs. In the end, the students formed or created dances for children. In telling stories, the students emphasized the moral values such as cooperation, environmental awareness, and appreciation.

The implementation of arts education in the workshop and in the seven villages could take place as a result of collaborative work among the students of UPI, the women as pioneers of POSDAYA, the children, and the community. The training model developed by the students of UPI is similar to the deductive model. Kamil (2003) explained that the deductive model has a clear problem for all participants. 


\section{CONCLUSIONS}

The implementation of arts education in society through community service programs conducted by UPI's students is a strategy to stimulate informal education in the family and the community. In the thematic program of the family empowerment post, students and advisors collaborated with the women pioneers of POSDAYAs to educate children through the arts and creative process that embed moral values. Through the program, the women in the seven villages in Parongpong, West Bandung, increase their knowledge and experiences about singing and dancing. Then, they created dances for children in the musical drama.

Dances for children created by adults were created in two steps. In the first step, adults were trained to sing, to dance, and to tell stories. We trained adults with arts education by modifying a synectic model offered by Masunah (2012). Syntactically, the training for adults begins with introducing the concepts, training the materials, exploring the movements, creating the dance, and presenting the dance. Teaching children in the community through practicing and presenting the musical drama is actually a tool to teach children moral values such as creativity, empathy, caring for others, politeness, and collaboration. These character traits represent living values which are important for children to live together in a pluralistic society. The thematic community service program related to the family empowerment post or other themes can be embedded in teaching arts education that embeds social values to motivate families educating their children through arts.

\section{REFERENCES}

Desfina. (2014). Tari Kreatif: Studi Kasus Tiga Guru Tari di Jawa Barat. Dissertation. Malaysia: Universitas Malaysia

Duta, E. (2015). Cerita dongeng edukasi dan pendidikan anak Indonesia (Ed- ucational tales and Indonesian children's education). [Online]: http:// www.ceritadongeng-ind onesia. blogspot.co.id/2015/08/si-kancilmencuri-timun.html? $\mathrm{m}=1$

Caturwati, E., et al. (2008). Tari anak-anak dan permasalahannya. Bandung: Sunan Ambu STSI Bandung Press.

Giguere, M. (2011). Dances for Children, with Children, and by Children: Looking at Recital Dance through a Lens of Children's Culture. Journal of Dance Education, 11(3), pp. 84-89.

Gilbert, A.G. (2002). Creative dance for all ages: a conceptual approach. Seventh printing. VA, U.S.A.: The American Alliance for Health, Physical Education, Recreation and Dance (AAHPERD).

Institute of Research and Community Service of UPI. (2016). Buku Panduan Kuliah Kerja Nyata Tematik Pos Pemberdayaan Keluarga (POSDAYA) UPI 2016. Bandung.

Joyce, M. (1994). First Step In Teaching Creative Dance. California: National Press

Kamil, M. (2003). Model-Model Pelatihan (Training models) (unpublished paper). Bandung.

Komariah, K. \& Saripudin, D. (2017). Pendidikan Karakter (Character education). Bandung: PT. Refika Aditama.

Kurniawati, L. (2015). "Pembelajaran Musik untuk Anak Usia Dini." in Masunah, J. (eds.). Pendidikan Seni dan Aplikasi Pembelajaran berbasis Kreativitas dalam Pengembangan Karakter Anak Usia Dini. Bandung: CV. Bintang Warli Atika.

Masunah, J. (2000). Sawitri Penari Topeng Losari. Jogjakarta: Tarawang.

Masunah, J., Milyartini, R., \& Tarsidi, D. (2012). "Pengembangan Model Pendidikan Seni bagi Siswa Berkebutuhan Khusus" Research report of Post-Graduate Grant]. Bandung.

Masunah, J. \& Narawati, T. (2012). Seni dan Pendidikan Seni. 2nd edition. Bandung: P4ST UPI.

Masunah, J. (2011). Pemuliaan Angklung 
melalui Model Desa Binaan berbasis Wisata Seni dan Budaya. Jurnal Seni EBudaya Panggung, 22(1), 1-15.

Murgianto, S. (1993). Ketika Cahaya Merah Memudar. Sebuah Kritik. Jakarta: Deviri Ganan.

Maralsih \& Herlinah. (2014). Creativity Education Model through Dance Creation for Students of Junior High School. Journal of Arts Research and Education, 14(2), 147-157. doi:http:/ / dx.doi.org/10.15294/harmonia. v14i2.3296

Nuh, M. (2013). Salinan Lampiran Peraturan Menteri Pendidikan dan Ke- budayaan Nomor 67 tahun 2013 tentang Kerangka Dasar dan Struktur Kurikulum Sekolah Dasar/Madrasyah Ibtidaiyah

Soedarsono, R.M (1998). Seni Pertunjukan Indonesia dalam Era Globalisasi. Jakarta: Directorate General for Higher Education, Ministry of Education and Culture.

Stoecker, R. (2005). Research methods for community change. Thousand Oaks: Sage Publication.

Utami, R. R. (2016). Kupu-Kupu Merah (unpublished story). Bandung. 